\title{
Need for vaccination of sewer workers against leptospirosis and hepatitis A
}

Centre de santé publique de Québec, 2601 De la Canardiène Québec, Québec, Canada G1J2G3

G De Serres

B Levesque

D Laliberté

N Boulianne

B Duval

Faculté de médecine vétérinaire, Université de Montréal, Montréal, Québec, Canada

R Higgins

Ministère de

1'Agriculture, des Pêcheries et de

l'Alimentation du Québec, Québec, Canada

M Major

Correspondence to:

Dr Gaston De Serres

Centre de santé publique de Québec, 2050 Boul René Lévesque Ouest, Ste-Foy, Québec, Canada G1V 2K8

Accepted 20 March 1995

Gaston De Serres, Benoit Levesque, Robert Higgins, Michel Major, Denis Laliberté, Nicole Boulianne, Bernard Duval

\begin{abstract}
Objectives-This study compared the prevalence of Leptospira interrogans and hepatitis A virus (HAV) antibodies in serum samples from sewer workers and controls.
\end{abstract}

Methods-A blood sample was obtained from 76 of the 101 municipal sewer workers (75\%) of Quebec City and from two controls matched to each for age and sex. Testing was done for antibodies against serovars of Leptospira icterohaemorragiae, bratislava, hardjo, grippotyphosa, and kennewicki (pomona) and hepatitis A.

Results-Sewer workers had a greater prevalence of antibodies against leptospirosis than controls $(12 \%$ v $2 \%, P=$ $0.003)$. In contrast, antibodies to HAV were not significantly more prevalent among workers than among controls $(54 \%$ v $49 \%, P=0.51)$. Prevalence of HAV antibodies increased significantly with age both among workers and controls $\left(\alpha^{2}\right.$ for trend, $\left.P<0.001\right)$. In contrast with younger workers, prevalence of $\mathrm{HAV}$ antibodies was greater among workers $\geqslant 40$ years than among their controls $(81 \% v 65 \%, P=0.04)$.

Conclusion-Leptospirosis continues to be a problem to sewer workers but hepatitis $A$ is apparently no longer a risk. The likely explanation is that leptospira are still abundant in the sewage system in contrast with HAV, which is only rarely to be found in sewage as a result of the generalised decrease in incidence of hepatitis $A$ in the past three decades. The decision to vaccinate sewer workers against hepatitis $A$ should take into account that it is impossible to avoid all contact with sewage fluid and, despite the fact that the actual incidence of hepatitis $A$ is low, there is a real possibility of sporadic exposure during a future outbreak.

(Occup Environ Med 1995;52:505-507)

Keywords: sewer workers; hepatitis A; leptospirosis; prevention; vaccination

Sewer workers are traditionally assumed to be at greater risk of acquiring infections than the general population. ${ }^{1}$ Leptospirosis has long been recognised among sewer workers ${ }^{23}$ and is transmitted by infected rats. These contaminate sewer water with their urine, which may contain large numbers of leptospira. Clinical manifestations of leptospirosis vary from nonspecific symptoms of infections (fever, headache, myalgia) to an icterohaemorrhagic fever caused by hepatorenal dysfunction, or to aseptic meningitis and, in rare cases, death. It has also been reported that sewer workers seem to be at greater risk of hepatitis $A{ }^{4}$ Hepatitis A virus (HAV) is excreted in stools and is likely to be encountered in water contaminated with faeces. ${ }^{5}$ Hepatitis A is a mild disease in young children, but it causes appreciable morbidity in adults.

Even if sewer workers use boots, coats, and gloves, they have contact with sewage fluids either accidentally or through routine maintenance operations. Sewer cleaning operations are mechanised in many countries and use a machine that propels water in pipes under high pressure to clear the silt. This operation produces large amounts of aerosols that come out through manholes. Generally, workers do not wear full face protection and they must look in the manhole to drive the machine. During this operation, their face is soaked by aerosols, and they experience cutaneous, respiratory, mucosal, and oral contact with sewage fluids.

The aim of this study was to compare the prevalence of Leptospira interrogans antibodies as well as HAV antibodies in serum samples from sewer workers with controls from the general population to evaluate the necessity of improving personal protection and providing vaccines for these workers.

\section{Materials and methods}

All municipal sewer workers from Quebec city area were contacted. Those who agreed to participate completed a questionnaire and had a blood sample drawn at work after signing a consent form approved by the Ethics Committees of the Centre Hospitalier de l'Universite Laval and of the Hôpital SaintSacrement, Québec. Information sought included the number of years in this type of work; history of jaundice, hepatitis, leptospirosis, meningitis, or any stay in hospital for infection; and risk factors for leptospirosis (previous work in a farm, butchers, or slaughterhouse, and the presence of pets at home). Two control serum samples, matched for age and sex, were selected for each sewer worker. These anonymous, unlinked serum samples came from outpatients who had undergone lipid testing.

Leptospiral antibodies were detected with 
Proportions of workers and controls with leptospiral and HAV antibody by age

\begin{tabular}{lllllr}
\hline & \multicolumn{2}{l}{ Leptospirosis } & & \multicolumn{2}{l}{ Hepatitis $A$} \\
\cline { 2 - 3 } $\begin{array}{lllll}\text { Age group } \\
(y)\end{array}$ & $\begin{array}{l}\text { Workers } \\
n(\%)\end{array}$ & $\begin{array}{l}\text { Controls } \\
n(\%)\end{array}$ & & $\begin{array}{l}\text { Workers } \\
(\%)\end{array}$ & $\begin{array}{l}\text { Controls } \\
n(\%)\end{array}$ \\
\hline $30-34^{\star}$ & 0 & $1 / 28(4)$ & $2 / 14(14)$ & $7 / 28(25)$ \\
$35-39$ & $2 / 21(10)$ & 0 & $7 / 21(33)$ & $16 / 42(38)$ \\
$40-44$ & $5 / 15(33)$ & 0 & $10 / 15(67)$ & $16 / 30(53)$ \\
$45-49$ & 0 & 0 & $11 / 13(84)$ & $18 / 26(69)$ \\
$50-54$ & $1 / 7(14)$ & $1 / 14(7)$ & $5 / 7(71)$ & $7 / 14(50)$ \\
$\geqslant 55$ & $1 / 6(17)$ & $1 / 12(8)$ & $6 / 6(100)$ & $11 / 12(92)$ \\
Total & $9 / 76(12)$ & $3 / 152(2)$ & $41 / 76(54)$ & $75 / 152(49)$ \\
\hline
\end{tabular}

^Includes one sewer worker aged 29 years and his two controls.

the microscopic agglutination test (MAT). Titres of 1:50 or greater were considered positive. Serovars tested were icterohaemorragiae, bratislava, hardjo, grippotyphosa, and kennewicki (pomona). The serovars were chosen according to those prevalent in animals and included in the veterinary surveillance programme of the Ministry of Agriculture of Canada. ${ }^{67}$ Icterohaemorragiae is well associated with rats, but all those tested could be found in rodents. The HAV antibody was measured with IM HAVAB microparticle enzyme immunoassay (Abbott Laboratories, Abbott Park, IL) according to the manufacturer's instructions.

\section{STATISTICAL ANALYSES}

Proportions were compared with $\chi^{2}$ or Fisher's exact test and trends were evaluated by $\chi^{2}$ for trend. Confounding was assessed by multivariate logistic regression.

\section{Results}

Of the 101 workers $76(75 \%)$ agreed to participate in this study. Those who refused did not differ from participants by their age or number of years of employment. All participants except two were men and all were born in Canada. Mean (range) age was 41 (28-64) years and the time at this work was $10(1-30)$ years. No worker reported a history of leptospirosis but five recalled having had jaundice before their employment. Information about previous use of pipe cleaning machines was lacking but the foremen reported that most workers used them sometime during their employment.

Sewer workers had a greater prevalence of antibodies against leptospirosis than controls

Proportion of workers and controls with $H A V$ antibody/age group.

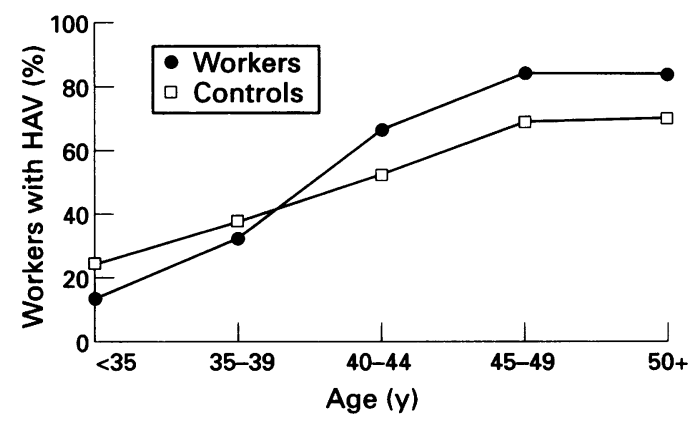

(12\% $v 2 \%, P=0.003)$. All positive subjects had a titre of 1:50 except one worker, who had a titre of $1: 100$. Among the 12 subjects with leptospiral antibodies, seven were positive for bratislava, four for hardjo, one for grippotyphosa, and none for icterohaemorrhagiae or kennewicki (pomona). None of the workers with leptospiral antibodies reported symptoms compatible with this disease during the past five years. The proportion of workers who were positive was not associated with age or the number of years at this work.

Overall, the proportion of workers with HAV antibodies was not significantly greater than among controls $(54 \% v 49 \%, \mathrm{P}=0.51$, table), but among both workers and controls, the proportion of positive subjects increased significantly with age $\left(\chi^{2}\right.$ for trend, $\mathrm{P}<0.001$, figure). In contrast with younger workers, the proportion of workers aged $\geqslant 40$ years who had HAV antibody was significantly greater than among controls $(81 \% v 65 \%, \mathrm{P}=0.04)$. In multivariate analysis, the proportion of workers who were positive was associated with age but not with the number of years at this work.

\section{Discussion}

This study shows that infection by leptospirosis continues to occur among sewer workers but that the risk of contracting hepatitis $\mathrm{A}$ has apparently been low for all sewer workers in recent years. The controls chosen in this study can reasonably be assumed to represent a valid sample of the overall population as testing for lipids is widely used in screening and is recommended for all healthy adults. Greater access to health care by higher socioeconomic class makes it possible that they might be less affected by both hepatitis $\mathrm{A}$ and leptospirosis. This is unlikely because health care is totally free in Canada. Moreover, prevalence of antibodies against HAV is lower in controls than in workers older than 40 years of age and the opposite is true for those younger than 40 years. This inversion of the risk suggests that our controls are not more "health conscious" or more at risk of hepatitis $A$ than the general population would be.

In contrast with $\mathrm{HAV}$, leptospiral antibodies do not persist for life. In fact, even if these antibodies can be found sometimes two to 10 years after an infection, generally antibody titres fall over weeks or months. ${ }^{8}$ Thus, the prevalence of leptospiral antibody does not have a lifelong cumulative incidence similar to HAV but is more likely to represent the incidence of only the recent years. ${ }^{9}$ False positive results are very unlikely with a titre of 1:50 in the MAT test, especially with bratislava and hardjo. ${ }^{810}$ This test is serovar specific, and cross reactivity with non-pathogenic serovars found in surface water, such as Leptospira biflexa, is not a problem. ${ }^{8}$ The greater risk of infection by leptospirosis in workers than in controls is similar to that mentioned in other studies. ${ }^{411}$ In our study, however, the increased risk of hepatitis A among sewer 
workers was only found among those older than 40 years, in contrast with other countries where the increased risk was found within all age groups. ${ }^{42-14}$ The decreased risk of hepatitis $A$ in our younger workers is unlikely to be attributable to improved working procedures because, unlike hepatitis $A$, we found that leptospiral infection continues to be a risk for sewer workers regardless of their age. The more likely explanation of our results is that leptospira are still abundant in the sewage system unlike HAV which has only a small probability of being found in sewage as a result of the generalised decrease in incidence of hepatitis $\mathrm{A}$ in the past three decades in the developed countries. ${ }^{15}$

Personal protection of these workers should be improved, especially for those who operate pipe cleaning machines. It is unlikely that even this will totally avoid the risk of infections. Leptospiral vaccines exist, but they are serovar specific, must be repeated every year, and are associated with a high incidence of painful swelling, especially after revaccination. ${ }^{16}$ Better vaccines should be developed before they can be widely used. In contrast, a safe and effective vaccine exists against hepatitis $\mathrm{A}$. The decision to vaccinate sewer workers against hepatitis A should take into account that it is impossible to avoid all contact with sewage fluid and, despite the fact that the actual incidence of hepatitis $A$ is low, there is a real possibility of sporadic exposure during a future outbreak.
We are indebted to Reine Roy and Rachel Chouinard, and to the supervisors and technicians of the biochemistry and haematology laboratories of the Hôpital St-Sacrement for their support. This study was funded by the Centre de santé publique de Québec and SmithKline Beecham Pharma.

1 Bell JH. Sewers. Encyclopedia of Occupational Health and Safety 1983;2:2019-21.

2 Hamilton Fairley N. Weil's disease among sewer workers in London. BMF 1934;10-4.

3 Waitkins SA. Leptospirosis as an occupational disease. $\mathrm{Br} \mathcal{F}$ Ind Med 1986;43:721-5.

4 Skinhoj P, Hollinger FB, Hovind-Haugen $K$, Lous $P$. Infectious liver diseases in three groups of Copenhagen workers: correlation of hepatitis $\mathrm{A}$ infection to sewage workers: correlation of hepatitis A infection to

5 Batik O, Craun GF, Tuthill RW, Kraemer DF. An epidemiologic study of the relationship between hepatitis A and water supply characteristics and treatment. $\mathrm{Am} \mathcal{F}$ Public Health 1980;70:167-8.

6 Higgins R, Cayouette P. Serological diagnosis of leptospirosis in the Province of Quebec. Canadian Veterinary fournal 1978;19:13-6.

7 Kingscote BF. Leptospiral serovars in Canada. Canadian Veterinary fournal 1988;29:70-1.

8 Faine S. Leptospira and leptospirosis. Boca Raton: CRC Press, 1993.

9 Blackmore DK, Schollum LM, Moriarty KM. The magnitude and duration of titres of leptospiral agglutinins in tude and duration of titres of leptosp
human sera. $N Z M$ Med $₹ 1984 ; 97: 83-6$.

10 Ellis WA. Problems in the diagnosis of leptospirosis. Symposium on leptospirosis. Laval, Quebec: Canadian society of microbiologist, veterinary section, 1989.

11 Chan OY, Chia SE, Nadarajah N, Sng EH. Leptospirosis risk in public cleaning and sewer workers. Ann Acad Med 1987;16:586-90.

12 Roudot-Thoraval F, Schlosser O. Hepatitis $A$ an occupational risk for workers exposed to sewage. Presented at the 6 th International symposium on viral hepatitis. Madrid. Vaccine Weekly 1994.

13 Heng BH, Goh KT, Doraisingham S, Quek GH. Prevalence of hepatitis A virus infection among sewage Prevalence of hepatitis A virus infection among sewage
workers in Singapore. Epidemiol Infect 1994;113:121-8.

14 Poole CJM, Shakespeare AT. Should sewage workers and carers for people with learning disabilities be vaccinated for hepatitis A? BMF 1993;306:1102.

15 Gust ID. Epidemiological patterns of hepatitis $A$ in different parts of the world. Vaccine 1992;10:56-8.

16 Faine S. Leptospirosis. In: Evans AS, Brachman PS, eds. Bacterial infections of humans. Epidemiology and control, 2nd ed. New York: Plenum Medical, 1991.

\section{Instructions to authors}

Three copies of all submissions should be sent to: The Editor, Occupational and Environmental Medicine, BMJ Publishing Group, BMA House, Tavistock Square, London WC1H 9JR, UK. All authors should sign the covering letter as evidence of consent to publication. Papers reporting results of studies on human subjects must be accompanied by a statement that the subjects gave written, informed consent and by evidence of approval from the appropriate ethics committee. These papers should conform to the principles outlined in the Declaration of Helsinki (BMF 1964; ii:177).
If requested, authors shall produce the data on which the manuscript is based, for examination by the Editor.

Authors are asked to submit with their manuscript the names and addresses of three people who they consider would be suitable independent reviewers. They will not necessarily be approached to review the paper.

Papers should include a structured abstract of not more than 300 words, under headings of Objectives, Methods, Results, and Conclusions. Please include up to three keywords or key terms to assist with indexing. 